\title{
The antecedent factors of organizational performance
}

\author{
Arista Natia Afriany \\ arista@upy.ac.id
}

Fakultas Bisnis, Prosa Manajemen, Universitas PGRI Yogyakarta

\begin{abstract}
Companies need human resources because, with competent human resources, good corporate governance will establish. This research aims to prove the effect of work motivation, work discipline, work environment on job satisfaction, and employee performance. The data in this research was gathered from 58 samples at PT XXX. The method in this research using structural analysis with smart PLS. The result shows that work motivation has an effect on job satisfaction, and job satisfaction has an impact on employee performance. But work discipline and work environment do not affect job satisfaction. The result clarifies that there are implications for companies to increase motivation and job satisfaction so that employee performance can be improved.
\end{abstract}

Keywords: $\quad$ Motivation; work discipline; work environment; job satisfaction; employee performance

\section{Introduction}

Organizations or companies both large and small companies will need human resources or employees to support their operations because employees are a crucial element for an inbetween input and output so that other resources available in the company can function adequately (Lumentut \& Dotulong, 2015). If all the resources in the company function properly, the company will quickly reach its goal. Therefore, if a company wants to develop and survive in business competition, employees must work properly. One way for companies to have employees who can work properly is to increase employee job satisfaction because, with job satisfaction, employee performance will improve (Fadhil \& Mayowan, 2018).

Employee job satisfaction is a significant factor for organizations because with employee job satisfaction, organizational performance will increase, and company goals are easily achieved (Wibowo 2012; Dhermawan et al., 2012). Employees, in general, need satisfaction in doing the work they are engaged in. Every employee has different job satisfaction at work, some employees are satisfied with the current situation, but some employees feel unsatisfied (Mustofa 2018). Some research states that work motivation, work discipline, work environment, and performance are related. Every employee has a different work motivation at work; some employees want an award given by the company where they work and satisfaction in doing a job that can only be felt by themself. High work motivation will encourage employees to work well. High work discipline will increase a sense of responsibility, and a comfortable work environment will create employee motivation to work well (Lumentut \& Dotulong, 2015; Haryati, 2013; Inbar et al., 2018).

This research was conducted because the results of previous studies were inconsistent. Several studies have found evidence that motivation, work discipline and work environment do not affect employee job satisfaction (Dhermawan, 2012; Lumentut \& 
Dotulong, 2015; Hadiwijaya \& Hanafi 2016; Susanty, 2012). However, other research states that motivation, work discipline and work environment influence employee satisfaction (Kartika \& Kaihatu, 2010; Mustofa, 2018; Wijayanti, 2013).

\section{Literature Review and Hypotheses Development}

\subsection{Performance}

Performance is a manifestation of work done by employees, usually used as a basis for evaluating employees or organizations. Performance is everything produced by a person in the form of products and services following knowledge and experiences (Hasibuan, 2012). Employee performance must be strived to improve because excellent employee performance is a step to achieving organizational goals, but to improve employee performance is not easy because many factors can improve performance, one of them is job satisfaction. Employee performance can be effect by job satisfaction, if satisfaction drops, employee performance also will decrease and vice versa (Supriyadi et al., 2017).

\subsection{Job Satisfaction}

According to Handoko (2012), job satisfaction is a pleasant or unpleasant emotional state that an employee feels when looking at his work. Or in other words, job satisfaction is a person's perspective or feeling towards their work. Job satisfaction is critical because if employees do not feel comfortable and are less valued, they won't be able to develop all their potential, then automatically employees can't entirely focus and concentrate on their work (Fadhil \& Mayowan, 2018).

Among the company's many goals is to make a profit and be the best to fulfill the needs of consumers. Based on these two things, the company is required to continue to productively make products with the best quality and sustainability (Saleh \& Utomo, 2018). To achieve the company's goals, employee job satisfaction is needed to run well. According to Martoyo (2008), Job satisfaction is a psychological aspect that reflects a person's feelings towards his work. Someone will feel satisfied with the suitability between abilities, skills, and expectations with the work they deal with.

\subsection{Work Motivation}

According to Wibowo (2012), motivation is a psychological process that generates and directs behavior to achieve goals. Motivation is the most crucial factor for an employee because it will encourage employees to do specific jobs. Therefore, high motivation will encourage employees to meet all job requirements so that job satisfaction can increase. Work motivation is the process of giving encouragement and support to work to the limits assigned to them to achieve optimal organizational goals. Motivation is the energy that moves individuals to try to make the expected goals (Sulistiyani, 2009; Torang, 2012).

\subsection{Work Discipline}

Discipline is generally defined as compliance and obedience to the rules or regulations that apply in the environment of each organization. If employees do not obey all the rules and regulations that apply in the work environment, it means that the employee's actions can be 
categorized as actions that violate discipline (Holil \& Sriyanto, 2011). Work discipline is a starting point for any success in achieving an organization's goals. The application of work discipline in an organization ensures that all employees in the company are willing to obey every order that applies without any forced voluntarily. Good work discipline can be seen from the high awareness of its employees in following all applicable rules and regulations, high responsibility for their duties, and increasing employee efficiency and performance (Lumentut \& Dotulong, 2015).

\subsection{Work Environment}

The work environment is everything around the employees who can affect themselves to do the work assigned. The work environment is a situation where the workplace, which includes the physical environment and non-physical environment, can give the impression of fun, safe, and peaceful. The work environment plays an important role in increasing motivation to realize the company's goals properly. A right work environment can be created if we pay attention to the elements that exist in the work environment. The physical work environment and non-physical work environment are expectations for employees (Inbar et al., 2018).

\subsection{Hypotheses}

Human resource management is knowledge or way of managing relationships, and the role of individuals efficiently and effectively can be used optimally to achieve common goals in an organization (Pomalingo et al., 2015). Work motivation is a stimulant for someone to act for a goal achievement set by the company to perform optimally. Employee performance is the achievement of work or tasks for their duties and responsibilities (Mahpudin \& Purnamasari 2018). As social beings, employees have a sense of mutual need for help from other employees in completing work. An employee also had a hope of improvement and be respected in their careers, so the pride and satisfaction feeling in his work will appear (Haryati, 2013). Lumentut \& Dotulong (2015); Kartika \& Kaihatu (2010); Wijayanti (2013) research results claim that high work motivation will improve employee performance. Based on the description above, a hypothesis is formulated:

\section{$H_{1}$ : Work motivation has a significant effect on employee satisfaction.}

A person who has a high level of discipline will continue to work well even if not supervised by superiors then will not steal work time to do other things that have nothing to do with work. And will obey the rules that exist in the work environment with a high ground without any force, which will ultimately affect the achievement of optimal performance (Haryati, 2013).

Work discipline is an obedient attitude to obey the rules based on self-awareness without any force from outside. Employees demand this kind of mentality as individuals and from groups of people who are members of the organization. With work discipline, employees can be more responsible for their duties so that their performance will be better (Pomalingo et al., 2015). The results of Saleh \& Utomo (2018) prove that work discipline has no significant effect on employee satisfaction. However, Sriyono (2017); Liyas \& 
Primadi, (2017) confirm that work discipline has a significant impact on employee satisfaction. Based on the description above, a hypothesis is formulated:

$\mathrm{H}_{2}$ : Work discipline has a significant effect on employee satisfaction.

There are two critical problems faced by management in managing companies, that is a human resource and the work environment. Human resources are significantly starting from the recruitment process, to the managing, because effective management will improve performance. Besides that, the work environment factors can also affect employee satisfaction. Therefore the company must create a comfortable work environment for employees (Sidanti 2015). The organization or company will implement several methods to maintain the employees, including creating a pleasant and conducive working atmosphere (Sari, 2018). Sidanti (2015); Arianto (2013) claims that the work environment does not significantly influence employee performance. Other research conducted by Potu (2013) argues that a sufficient work environment will improve employee performance.

\section{$H_{3}$ : The work environment has a significant effect on employee satisfaction.}

Job satisfaction is a positive attitude or negative attitude of employees on the work. Positive job satisfaction can increase company stability and performance, while negative job satisfaction can interfere with company stability and performance. Negative attitudes must be avoided because it will cause adverse effects for employees, such as increased turnover and high employee absences (Wibowo 2012).

The results of the study by Pudjiastuti \& Sriwidodo (2011) explained that job satisfaction affects performance. Excellent employee job satisfaction will improve employees' efficiency and performance (Lumentut \& Dotulong 2015; Dhermawan et al., 2012). Based on the description above, a hypothesis is formulated:

$H_{4}:$ Job satisfaction has a significant effect on employee performance.

\section{Research Method}

This study's population is the entire management of PT XXX Yogyakarta and all of the employees, with a total of 58 people as research respondents. The data used in this research are primary data obtained from respondents' responses to the questionnaire. This study's sampling technique is a saturation sampling used to the entire population as a research sample (Budiarto, 2019). All questions on the questionnaire use a 5 points scale from 1 (strongly disagree) to 5 (strongly agree).

\section{Operationalization of Variables}

Employee performance is the work of employees who are by their authority and responsibilities following organizational goals (Fadhil \& Mayowan, 2018). Employee performance is measured by 5 question items with the following indicators: a) I was able to complete the task entirely; b) The results of the work are matched with the target and amount; c) Work can be completed on time; d) Work can be completed maximum according to ability; e) Work can be completed independently 
Job satisfaction shows the compatibility between an expectation of a real job and the rewards gained from the situation (Kartika \& Kaihatu, 2010). Job satisfaction is measured using 9 question items with the following indicators: a) I am satisfied with my current job; b) I have the knowledge and experience in carrying out my duties; c) The company provides salary according to my workload; d) The pay I receive is equal to other employees; e) I get a vast opportunity in career development; f) Job promotion by the company is perfect; $g$ ) The leader always directs when facing severe tasks; h) My leader always motivates me at work; i) In carrying out the task, other workers always provide support

Work motivation is a process that causes an employee to behave in a job so that he feels he is getting what he can meet the needs such as salary, welfare, security and comfort (Kartika \& Kaihatu, 2010). Work motivation variables are measured by 10 question items with the following indicators: a) My salary is enough to provide my needs; b) The bonus given by the company is perfect; c) The company offers incentives fairly; d) The company provides absolute career guarantees; e) My job offers insurance for retirement; f) I have a good relationship with other workers; g) The results of my work always get praise from the leadership; h) I always get a reward for my achievements; i) I was involved in the decisionmaking; j) I participate in essential company activities.

Discipline is a process that can grow someone's feelings to maintain and improve organizational goals objectively through obedience to implementing corporate regulations (Saleh \& Utomo, 2018). The work discipline variable is measured by 8 question items with the following indicators: a) I can attend on time; b) Presence is significant in establishing discipline; c) I always obey company rules; d) Do the work according to the leader's instructions; e) Not accepting another job even though the salary is higher; $f$ ) If there is additional work that can be done on time; g) I help other workers when needed; h) I work according to the assigned time.

The work environment is a situation where an employee works, so they have a feeling of the atmosphere in the place they work (Saleh \& Utomo, 2018). Work environment variables are measured by 6 question items with the following indicators: a) I feel comfortable with my current place of work; b) The environment is well-organized; c) The facilities provided by the company fit my needs; d) I can interact with all other workers; e) Other workers can easily work well together; f) Bosses always make the right decisions.

\section{Result}

The study was conducted to determine the effect of work motivation, work discipline, and work environment on job satisfaction and performance. In the first stage of this study will analyze the description of respondents presented in table 1. After an analysis of the demographics of respondents based on data analysis methods described in the research method, the first test is the path analysis, the second is testing the model fit, and the third is testing the hypothesis. 
Table 1. Description of respondents

\begin{tabular}{clrcc}
\hline No. & & Gender & Amount & Percentage \\
\hline 1 & Gender & Male & 20 & $34,5 \%$ \\
& & Female & 38 & $65,5 \%$ \\
2 & \multirow{2}{*}{ Age } & $<25$ years & 5 & $8,0 \%$ \\
& & $25-30$ years & 20 & $34,5 \%$ \\
& & $30-35$ years & 15 & $26,0 \%$ \\
& & $>35$ years & 18 & $31,5 \%$ \\
3 & \multirow{2}{*}{ Years of work } & $<5$ years & 16 & $27,5 \%$ \\
& & $5-10$ years & 24 & $41,0 \%$ \\
& & $>10$ years & 18 & $31,5 \%$ \\
\hline
\end{tabular}

\subsection{Path Analysis}

The path analysis results use a structural model because of its ability to measure the construct through the indicators and analyze indicator variables and latent variables. The results of the path analysis are shown in Figure 1.

\section{Figure 1. Model Test Results}

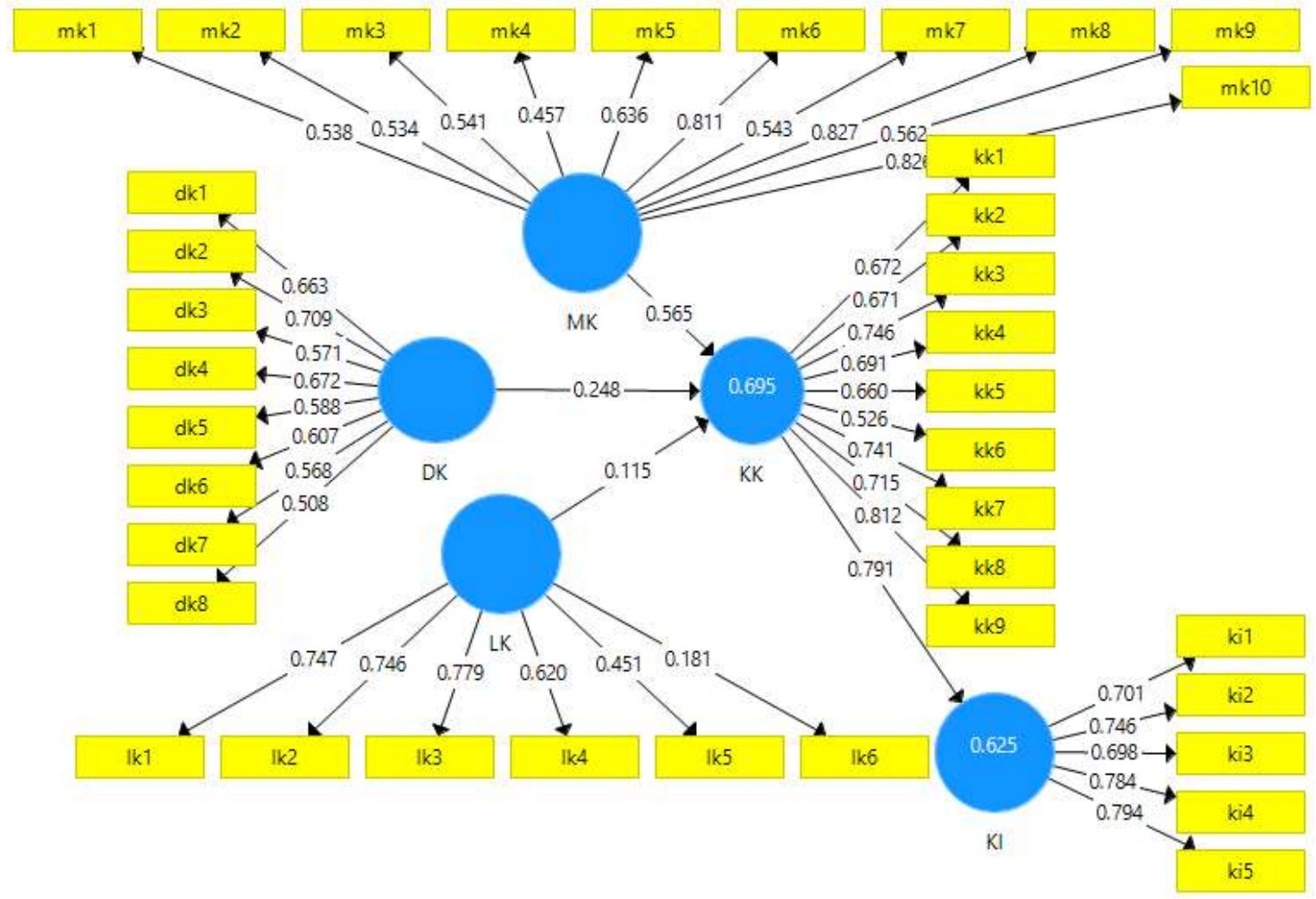

\subsection{Convergent Validity}

Convergent validity is used to test the validity of the instrument, which is an indicator variable. To verify the convergent validity, the outer loading or Loading factor value is used. Figure 1 shows that the loading factor value for all variables is $>0.5$ (valid) except for the work environment indicators, namely Lk 5 and LK 6, and MK 4 work motivation, so these three indicators, need further testing. 


\subsection{Discriminant Validity}

This section will describe the results of the Discriminant validity test. The discriminant validity test uses cross-loading values. An indicator is proven to meet Discriminant validity if the cross-loading indicator value on the variable is the largest compared to other variables. The table below is the cross-loading value of each indicator.

Table 2. Results of Discriminant Validity of Work Motivation Variables

\begin{tabular}{cccccc}
\hline Instruments & MK & KK & DK & LK & KI \\
\hline Mk1 & 0,538 & 0,672 & 0,663 & 0,747 & 0,701 \\
Mk2 & 0,534 & 0,671 & 0,709 & 0,746 & 0,746 \\
Mk3 & 0,541 & 0,746 & 0,571 & 0,779 & 0,698 \\
Mk4 & 0,457 & 0,691 & 0,672 & 0,620 & 0,784 \\
Mk5 & 0,636 & 0,660 & 0,588 & 0,451 & 0,794 \\
Mk6 & 0,811 & 0,526 & 0,607 & 0,181 & \\
Mk7 & 0,543 & 0,741 & 0,568 & & \\
Mk8 & 0,827 & 0,715 & 0,508 & & \\
Mk9 & 0,562 & 0,812 & & & \\
Mk10 & 0,826 & & & & \\
\hline
\end{tabular}

\subsection{Composite reliability}

Composite reliability is a part that is used to test the reliability value of indicators on a variable. A variable can be proven to fulfill composite reliability if it has a composite reliability value $>0.6$. The results of the composite reliability test are shown in table 3 .

Table 3. Reliability Test Results

\begin{tabular}{lcc}
\hline \multicolumn{1}{c}{ Variable } & Composite reliability & Explanations \\
\hline Work Motivation (MK) & 0,870 & Reliable \\
Work Discipline (DK) & 0,827 & Reliable \\
Work Environment (LK) & 0,772 & Reliable \\
Job Satisfaction (KK) & 0,893 & Reliable \\
Performance (KI) & 0,862 & Reliable \\
\hline
\end{tabular}

\subsection{Model Testing}

Model testing can be done based on the adjusted $\mathrm{R}$ square value generated in the analysis using PLS. The analysis showed that the adjusted R square value in the first model was 0.625 and in the second model it was 0.695 .

Table 4. Testing of Adjusted R Square

\begin{tabular}{lc}
\hline \multicolumn{1}{c}{ Exogenous Variable } & Adjusted R Square \\
\hline Job Satisfaction & 0,674 \\
Performance & 0,617 \\
\hline
\end{tabular}




\subsection{Hypotheses Testing and Discussion}

Hypotheses testing is done by looking at the $\mathrm{p}$ value in each proposed equation model. If the value of $p$ value $<5 \%$, the hypothesis is proven. Hypothesis testing results are shown in table 5.

Table 5. Hypotheses Test Results

\begin{tabular}{cccl}
\hline Hypotheses & t statistic & P value & \multicolumn{1}{c}{ Remarks } \\
\hline $\mathrm{MK} \rightarrow \mathrm{KK}$ & 3,961 & $0,000^{* *}$ & $\mathrm{H}_{1}:$ accepted \\
$\mathrm{DK} \rightarrow \mathrm{KK}$ & 1,350 & 0,178 & $\mathrm{H}_{2}:$ rejected \\
$\mathrm{LK} \rightarrow \mathrm{KK}$ & 0,744 & 0,458 & $\mathrm{H}_{3}:$ rejected \\
$\mathrm{KK} \rightarrow \mathrm{KI}$ & 9,370 & $0,000^{* *}$ & H4: accepted \\
\hline
\end{tabular}

$* * \operatorname{sig}<1 \%$

The test results show that work motivation has a significant effect on employee satisfaction. This study supports previous research, which explains that high motivation will encourage employees to work better (Pomalingo et al., 2015). Resources owned by the company are the key to success in achieving organizational goals. If employees have high motivation to work, they will have behavior that is following company goals, the higher the motivation, the higher the employee will have higher job satisfaction (Mahpudin \& Purnamasari, 2018). On the other hand, employees have hopes and opportunities to make progress in their careers, want to be valued and respected, so that pride and confidence arise. This means encouraging employee work motivation to a higher level so that the employees will contribute to the achievement of organizational goals (Haryati, 2013). Kartika \& Kaihatu (2010) claim that the higher the motivation of employees to work, the higher the job satisfaction of employees.

The results of this study support previous research, which claims that work discipline does not significantly influence job satisfaction (Susanty 2012). The interviews with employees prove that some employees still work even though not supervised by superiors. Although some employees are often late to attend at the office, this does not interfere with employee job satisfaction. This means that employees have a sense of responsibility for each task and increase efficiency (Lumentut \& Dotulong, 2015). This is a concern for companies to improve work discipline so that job satisfaction can be further enhanced.

The results of this study indicate that the work environment has no significant effect on job satisfaction. These results are not match with previous research which claims that the work environment will determine a person's comfort at work. The better working environment will lead to the achievement of performance and vice versa, less comfortable work environment will reduce employee performance (Arianto, 2013; Sidanti, 2015). Based on the results of interviews with employees showed that many employees who work outside the office because the work environment is not comfortable, but this does not reduce employee motivation and does not reduce the level of employee job satisfaction. This is an interesting concern for companies to increase rewards for employees due to the high commitment for the company. A comfortable and conducive work environment will increase motivation and vice versa, a non-conducive work atmosphere will reduce work motivation (Dhermawan et al, 2012). 
High performance can be created if employees have job satisfaction, so they feel happy and comfortable. Therefore, employees will achieve maximum work results following their desires, and with high performance, the company can get the desired benefits (Fadhil \& Mayowan, 2018). This study's findings are developing the concept of motivation in the form of feelings that employees have, so it will encourage them to do work as they wish. This means that high job satisfaction can be obtained from high work motivation (Mustofa, 2018).

\section{Conclusion, Limitation, Suggestions}

The results showed that work motivation affects job satisfaction, and job satisfaction affects performance. However, work discipline and work environment do not affect job satisfaction. This research was conducted by distributing questionnaires to obtain data. Future research should be done by other methods such as interviews and more in-depth observations, so the better research results are achieved. This research was only conducted at one company, so only a small sample size was obtained. For future research, it is better to add research objects with more samples so that the research results can be generalized. This study only examined the variables of motivation, work discipline, and work environment. Future research can add other variables related to employees' psychological factors, such as organizational culture, leadership style, and organizational commitment, social factors of employees such as human relations, or can also relate it to employee performance.

\section{References}

Arianto, D. A. (2013). Pengaruh kedisiplinan, lingkungan kerja dan budaya kerja terhadap kinerja tenaga pengajar, Economia, 9(2), 191-201.

Budiarto, D. S. (2019) Panduan Riset Kuantitatif: Trik Publikasi Bagi Pemula, UPY Press Yogyakarta.

Dhermawan, A.A.N., Sudibya, I.G.A,. \& Utama, I.W.M. (2012). Pengaruh motivasi, lingkungan kerja, kompetensi, dan kompensasi terhadap kepuasan kerja dan kinerja pegawai di lingkungan kantor Dinas Pekerjaan Umum Provinsi BALI. Jurnal Manajemen, Strategi Bisnis, dan Kewirausahaan, 6(2), 173-185.

Fadhil, A., \& Mayowan, Y. (2018). Pengaruh motivasi kerja dan kepuasan kerja terhadap kinerja karyawan AJB BUMIPUTERA. Jurnal Administrasi Bisnis, 54(1), 40-48.

Hadiwijaya, H., \& A, Hanafi. (2016). Pengaruh kompetensi dan disiplin terhadap kepuasan serta implikasinya pada prestasi kerja karyawan. Jurnal Manajemen \& Bisnis Sriwijaya, 14(3), 407-419.

Handoko, H. (2012). Manajemen Personalian dan Sumber daya Manusia. BPFE : Yogyakarta.

Haryati, D.J. (2013). Pengaruh motivasi, disiplin dan lingkungan kerja terhadap kinerja pegawai pada Dinas Kesehatan Kota Cimahi Jurnal Ekonomi, Bisnis \& Entrepreneurship, 7(2), 84-94.

Hasibuan, M (2012). Manajemen Sumber Daya Manusia dan Kunci Keberhasilan. Jakarta: Haji Mas Agung.

Holil, M., \& Sriyanto, A. (2011). Pengaruh motivasi dan disiplin kerja terhadap kinerja pegawai (Studi kasus Kantor Pelayanan Pajak Badan Usaha Milik Negara). Jurnal 
Fakultas Ekonomi Universitas Budi Luhur. http://fe.budiluhur.ac.id/wpcontent/uploads/2011/05.Hal.22-38

Inbar, N.R.D., Astuti, E.S., \& Sulistyo, M.C.W. (2018). Pengaruh lingkungan kerja terhadap disiplin kerja dan semangat kerja karyawan (Studi pada Karyawan PDAM Kota Malang). Jurnal Administrasi Bisnis, 58(2), 84-93.

Kartika, E.W., \& Kaihatu, T. S. (2010). Analisis pengaruh motivasi kerja terhadap kepuasan kerja (Studi kasus pada karyawan Restoran di Pakuwon Food Festival Surabaya). Jurnal Manajemen dan Kewirausahaan, 12(1), 100-112.

Liyas, J.N., \& Primadi, R. (2017). Pengaruh disiplin kerja terhadap kinerja karyawan pada Bank Perkreditan Rakyat. Al Masraf: Jurnal Lembaga Keuangan dan Perbankan, 2(1), 18-28.

Lumentut, M.D.S., \& Dotulong, L. (2015). Pengaruh motivasi, disiplin, dan lingkungan kerja terhadap kepuasan kerja karyawan pada PT. Bank Sulut Cabang Airmadidi. Jurnal $E M B A, 3(1), 74-85$.

Mahpudin, E., \& Purnamasari, P. (2018). Pengaruh motivasi kerja terhadap kinerja karyawan pada PT BCA. Jurnal Edunomic, 6(2) 66-78

Martoyo, S. (2008). Manajemen Sumber Daya Manusia, BPFE, UGM Yogyakarta.

Mustofa, N (2018). Pengaruh motivasi, disiplin kerja dan lingkungan kerja terhadap kepuasan karyawan di Apotik Sumber Anom Warujayeng Nganjuk. Jurnal SimkiEconomic, 02(01), 10-21.

Palupi, M. (2013). Pengaruh keadilan kompensasi, kebijakan rotasi karyawan dan komitmen afektif pada perilaku retaliasi PNS kantor "X" di Yogyakarta. Jurnal Riset Manajemen dan Bisnis, 8(1), 15-24.

Potu, A. (2013) Kepemimpinan, motivasi, dan lingkungan kerja pengaruhnya terhadap kinerja karyawan pada Kanwil Ditjen Kekayaan Negara Suluttenggo dan Maluku Utara di Manado. Jurnal EMBA, 1(4), 1208-1218

Pudjiastuti, E., \& Sriwidodo, U. (2011). Pengaruh kompetensi, disiplin kerja, dan kepuasan kerja terhadap kinerja SMP Negeri 1 Purwodadi Grobogan. Jurnal Manajemen Sumberdaya Manusia, 5(2), 120 - 131.

Pomalingo, R., Mandey, S. L., \& Uhing, Y. (2015). Pengaruh disiplin kerja, kompetensi, dan motivasi terhadap kinerja pegawai pada Kantor Badan Penaggulangan Bencana Daerah Sulawesi Utara. Jurnal Berkala Ilmiah Efisiensi, 15(10), 528-537

Saleh, A.R., \& Utomo, H. (2018). Pengaruh disiplin kerja, motivasi kerja, etos kerja dan lingkungan kerja terhadap produktivitas kerja karyawan bagian produksi di PT. Inko Java Semarang. Among Makarti, 11(21), 28-51.

Sari, E. (2009). Pengaruh kompensasi dan iklim organisasi terhadap kepuasan kerja, bisnis \& birokrasi. Jurnal Ilmu Administrasi dan Organisasi, 16(1), 8-24.

Sidanti, H. (2015). Pengaruh lingkungan kerja, disiplin kerja dan motivasi kerja terhadap kinerja Pegawai Negeri Sipil di Sekretariat DPRD Kabupaten Madiun. Jurnal JIBEKA, 9(1), $44-53$.

Sriyono, H. (2017) The effect of self-concept, motivation and discipline on the performance of the primary school principals at Jakarsa regency of South Jakarta. International Journal of Human Capital Management, 1(1), 95-114.

Supriyadi, M.F., Priyadana, S., \& Setia, B.I. (2017). Kompensasi dan disiplin kerja terhadap kepuasan kerja karyawan Di Restoran Kampoeng Daun. Jurnal Riset Bisnis dan Manajemen, 10(2), 24-33. 
Sulistiyani, R. (2009). Manajemen Sumber Daya Manusia. Edisi Kedua. Penerbit Graha Ilmu. Yogyakarta.

Susanty, E. (2012). Pengaruh iklim organisasi terhadap kepuasan kerja dan komitmen karyawan pada universitas terbuka, Jurnal Organisasi dan Manajemen, 8(2), 121-134.

Torang, S. (2012). Organisasi dan Manajemen (Perilaku,Struktur, Budaya \& perubahan Organisasi). Cetakan Kesatu. Penerbit Alfabeta, Bandung.

Wibowo (2012). Manajemen Kinerja. Jakarta: Raja Grafindo Persada

Wibowo, M. M., Musadieq., \& Nurtjahyono, G.E. (2014). Pengaruh lingkungan kerja terhadap kepuasan kerja karyawan. Jurnal Administrasi Bisnis, 16(1), 1-15.

Wijayanti, D.P. (2013) Pengaruh motivasi terhadap kepuasan kerja pada karyawan KPRI "Pertaguma" Kota Madiun. Equilibriumn, 1(2), 199-206. 